\title{
Reframing Musical Learning in Schools Under Siege
}

\section{Deborah Bradley and Scott Goble, Editors}

his issue of Action, Criticism, and Theory for Music Education is our first
publication as ACT's new co-editors. Our aim in this introduction is to give
readers a taste of the exciting presentations and discussions that emerged at the MayDay Group's 3oth Colloquium, held at the University of Western Ontario in London, Ontario, Canada, in June 2018. The colloquium focused on MayDay Group Action Ideal VII:

An ongoing reflective effort towards understanding the context of music curriculum and education must serve as a common starting point for nurturing robust communities of music educators and learners. We are committed to engaging in a discussion which reframes all musical learning, including what takes place in schools, as a lived and diverse set of practices that encourages practitioners to be critically reflexive towards concepts of music pedagogy and curriculum as well as those practices represented in local, national, and global paradigms in education.

Those in attendance at Colloquium 30 heard many outstanding, challenging provocations, a number of which revealed concern with the effects of neoliberalism on contemporary music education. Neoliberalism is a complex, slippery economic dogma whose tendrils are becoming woven into education in profound and disturbing ways. The authors of the various articles in this issue of ACT each address, in their own way, effects of neoliberalism on music educators' thought processes, their daily lives as teachers, and on the field of education.

The first article in this issue is the keynote address given by noted scholar and cultural critic Henry Giroux at Colloquium 30. Giroux voiced alarm at the rise of neoliberal capitalist ideology in nations throughout the world, noting especially its effects on higher education, particularly in the United States under the regime of

(C) Deborah Bradley and Scott Goble. The content of this article is the sole responsibility of the author. The ACT Journal and the Mayday Group are not liable for any legal actions that may arise involving the article's content, including, but not limited to, copyright infringement. 
Donald Trump. Cogently characterizing this ideology as "market fundamentalism," Giroux explained that the neoliberal conception of freedom does not entail personal liberty balanced with social responsibility, but rather "removing one's self from any sense of social responsibility so one can retreat into privatized orbits of self-indulgence and unbridled self-interest" (see Giroux this issue). Correspondingly, he noted, agents of neoliberalism have collapsed education into training, reworking colleges and universities "to adopt the mission of business schools." $\mathrm{He}$ pinpointed neoliberal efforts to narrow the curriculum and advance illiteracy as a "willful practice and goal used to actively depoliticize people and make them complicit with the forces that impose misery and suffering upon their lives."

Acknowledging the grim prospects of a world set in neoliberalism's narrow frame, Giroux highlighted an essential role of education in a democracy: To "provide a basis for citizens' imagining of life beyond a social order characterized by inequality." Such an education involves teaching all students how to think critically, to embrace the common good, to exercise a sense of social responsibility, and to support the values, feelings, and ethical and political foundations needed for democracy to succeed. Among several specific recommendations, he called upon educators to reassert higher education's mission as a public good in order to reclaim egalitarian and democratic values. Giroux concluded by exhorting teachers to develop discourses of both critique and possibility: "Critical analysis is necessary to ... hold power accountable, and to reveal the workings and effects of oppressive and unequal relations of power. But critique without hope is a prescription for cynicism, despair, or civic fatigue." Educators must therefore shoulder responsibility for bringing hope to their students and helping to restore equity and justice in society.

In their article, "Reconceptualizing 'music-making:' Music technology and freedom in the age of neoliberalism," Cathy Benedict and Jared O'Leary observe that recent corporate and government initiatives supporting preparation of students for careers in computer science and technology-as well as computer technologies themselves-not only serve to benefit tech corporations' financial interests, but also limit students' creative and expressive options. This is evident in school music classes where students' creative musical choices have become limited by the restrictive parameters of the computer technologies available to them. To maintain and support students' personal creative and expressive intentions, Benedict and O'Leary suggest that students must also learn how to modify existing 
music technologies to serve their own purposes. They provide the example of musicians in the "chipscene"-a musical subculture whose members have learned to modify the codes used to create music in existing computer and video games-to support their liberating vision. Benedict and O'Leary's article raises important questions about the curricular limitations, possibilities, and topical boundaries of music classes, as well as the potentially deterministic effects of mass-produced technologies on students' personal and artistic freedom, in a society where an encroaching corporate economic agenda threatens to restrict them further.

Matias Recharte, in "De-centering Music: A "sound education," urges readers to reconsider the ways the word "music" is generally deployed in Western-centric societies and in the field of music education in particular, explaining why musiclike all the arts-is better considered as a politically active discourse. Recharte recognizes that the contemporary conception of "music," as broadly signified by that word and shared by music educators, is neither politically neutral nor a cultural universal, having roots as it does in the episteme of $18^{\text {th }}$ century Europeans. Indeed, although the concept has expanded over time, it has been used historically to exclude the sounds of outsiders, including African-Americans, Latinos, and others, both societally and within music education. Eschewing past instrumentalist conceptions of music education, Recharte proposes an alternative educational framework informed by scholarship from the emerging, interdisciplinary field of sound studies (which takes all sounding phenomena as its subject) and acoustemology (ethnomusicologist Stephen Feld's theorized conjoining of acoustics and epistemology), and he proffers listening indiscriminately to sounds and soundmaking as the foci of a proposed "sound education" informed by positionality and historicity. The vision of a "sound education" that Recharte provocatively advances is not unproblematic, but it holds promise as a proposal for equipping students to think with nuanced criticality about the relational dimensions of the sounds they encounter and those they create (including "music") in a time characterized by increasing cultural tensions.

In another article with direct links to Giroux's concerns about neoliberalism, Jess Mullen writes about "Music Education for Some: Music Standards at the Nexus of Neoliberal Reforms and Neoconservative Values." Mullen provides us with a practical look at the effects of neoliberal standardization, accountability measures, and the underlying assumption that competition will lead to better education for all students. These effects lead to the tensions music educators 
experience when they seek to provide a democratic education and encourage students' creativity. While much has already been written and said on these topics, Mullen takes us a step further in his argument--that such neoliberal educational reforms (as in the National Core Arts Standards), which purport to make music education more equitable through standardization, effectively support neoconservative values that seek to uphold Eurocentric notions of musical value. Mullen's description of how neoliberalism operates within education generally and music education specifically offers a helpful perspective on the forces affecting teachers in today's North American classrooms as they seek to prepare students primarily for the workforce under a neoliberal agenda, while simultaneously upholding a value system that looks to romanticized notions of the past as a way to preserve "traditional values" in an increasingly multicultural society. Mullen concludes with some thoughts on how to resist the "hegemonic alliance" of neoliberalism and neoconservatism in music education through democratic education practices that enable students to engage with the music of their daily lives.

Juliet Hess and Brent Talbot challenge educators to "go for broke" in their article, which takes James Baldwin's 1963 “A Talk to Teachers” as its jumping-off point. (Giroux mentioned this same Baldwin article in his address.) Going for broke in their argument requires tackling the difficult conversations that may arise around race and other topics sometimes deemed "too political" for the classroom. The direct connection they make between Baldwin's words and the "dangerous times" which we face in today's world seeks to offer music educators "a way for music and music education to challenge injustice and contribute to social change," beginning with recognition of and discussion in the classroom about the various political forces that affect our daily lives. Their concerns emerge in opposition to current discourses that endorse the ideology of white supremacy and white nationalism and thus resonate with Giroux's arguments against "unapologetic forms of white supremacy, bigotry, and the growing tactics of a police state [that] undermine the democratic mission of educational institutions in an age of increasing tyranny."

Following from a discussion of the intersections of oppressions (e.g., race with gender, race with class, gender with class), Hess and Talbot discuss the legacy of slavery and its contribution to the continuing racism evident in the present time. In this argument, they focus on slavery's lingering effects on today's "racial caste system" and its intertwining with social class. The article concludes with a model 
of activism in the musical world rooted in an analysis of A Tribe Called Quest's 2017 Grammy performance of "We the People," through which they challenge educators to explore oppression in society through music.

Although arguing from a perspective very different from that of Hess and Talbot, Vincent Bates challenges readers to think deeply about what the intersectionality of oppressions might mean in material terms and in research in "Standing at the Intersection of Class and Race in Music Education." Like Hess and Talbot, Bates walks readers through the history of the intersection of race and class in the U.S., making the argument that although antiracists frequently invoke the concept of intersectionality in their arguments, the focus of those arguments often stays solely on race. Citing the relative lack of social justice research in music education that utilizes class analysis, Bates challenges readers to think about whether focusing on class might offer an alternative perspective that could benefit educators, researchers, and, most importantly, those who may otherwise be overlooked (and forgotten) in analyses that focus solely on race. His argument, too, resonates with Giroux's important question: "What happens to a society in which 400 families own as much wealth has half the population?"

Readers may benefit from reading these last two articles together, to note where the authors' perspectives converge and diverge, illuminating in distinctive ways neoliberalism's (or neoliberal fascism's) role in perpetuating a wide range of social injustices. We hope you will consider how the differing perspectives, including the theoretical tensions, in these two articles provide a more comprehensive picture of social justice in music education.

Whether the recent advance of neoliberal capitalist ideology and authoritarian leadership in nations throughout the world (as observed by Giroux) represents a transitory historical divergence or a harbinger of widespread social disaster remains to be seen. In either case, the authors whose articles comprise this issue of ACT have provided music educators with strong examples of how critical analysis in our field can help to support egalitarian and democratic values in society, and thus also provide a good basis for instilling hope in our students for a more just and equitable future.

Bradley, Deborah, and Scott Goble. 2019. Reframing musical learning in schools under siege. Action, Criticism, and Theory for Music Education 18 (1): 1-5. doi:10.22176/act18.1.1 